\title{
DOCUMENTOS INÉDITOS \\ SOBRE LA AMETRALLADORA Y LA CODORNIZ DE MIGUEL MIHURA
}

José Antonio LlerA

I.E.S.

\section{Preliminar}

La llamada «otra generación del 27» ha venido concitando en los últimos años un creciente interés entre historiadores y críticos. La paternidad del rótulo hay que atribuírsela al discurso de ingreso en la RAE de José López Rubio (1983), aunque aproveche un viejo artículo publicado por Pedro Laín Entralgo en La Gaceta Literaria. El discurso de López Rubio no es más que un intento de construir una cédula de incorporación al canon a partir de una palabra taumatúrgica en nuestra historiografía literaria: generación. Se trata de un texto escrito en legítima defensa de un grupo de humoristas a quienes en vida les importaron poco los manifiestos colectivos, afines en su estética pero irreductiblemente individualistas, conscientes de estar moviéndose en una longitud de onda parecida -el humorismo y el cine-aunque decididos a no dejarse absorber del todo por un estilo comunitario que algunos no dejaron de ensayar firmando obras en colaboración. Más allá de los vínculos literarios y la amistad sincera que describe el autor del citado discurso, la relación entre los miembros más destacados -Mihura, Neville, Tono, Jardiel Poncela y López Rubio- estuvo también plagada de rupturas, celos profesionales, medias verdades y matrimonios de conveniencia. Uno de los documentos más interesantes que lo corrobora es la vitriólica carta que dirige Enrique Jardiel Poncela a Miguel Mihura, cuyo original se conserva entre los papeles personales 
de éste último'. Dice el autor de Amor se escribe sin hache: «La influencia en literatura es lícita $-\mathrm{y}$ yo he influido a alguno que otro-; lo que ya no es lícito es el plagio. Los hijos nacen influidos de sus padres, pero no los plagian jamás. El plagio en este caso es tan patente que cuando tú comenzabas a publicar mucha gente me preguntó si era yo quien lo hacía con seudónimo». Una auténtica ansiedad de la influencia (recordemos a Harold Bloom), levantada sobre los mitos de lo originario ${ }^{2}$ y de lo nuevo, afines a la poética vanguardista, y que aquí reaparecen a la luz de un enfrentamiento personal. Jardiel, que olvida sus deudas manifiestas hacia Gómez de la Serna y sobre todo hacia la novelística de Pitigrilli, continúa con una extenuante lista de agravios en la que salen a relucir secciones y recursos humorísticos sustraídos presuntamente por el discípulo. El tono de la misiva se enciende hasta llegar a la amenaza. Jardiel le reprocha a Mihura no ser más que un señorito parvenu, mientras que él da de comer a su familia con la pluma:

Poco a poco fuiste apropiándote mis maneras de hacer y obligándome a que yo las desechase de mi tintero (lo que resultaba excesivo) hasta el punto de que cuando inicié colaboración en Gutiérrez tuve que dejar de hacer «Argumentos de películas» [...] porque eran exactos a los que tú hacías, aunque con las diferencias lógicas, pues lo asimilado jamás consigue todas las virtudes del original y sí asimila muchos de sus defectos.

[...] No. Diocleciano y Nerón no se hubieran atrevido a tanto. Ni nadie que no sea yo, te habría aguantado tanto tampoco...

Pero ya me he cansado, Miguel. He resistido mucho y tenía que estallar. Todo tiene sus límites: hasta la provincia de Badajoz (y este volatín también pertenece al grupo de los que tú me coges) [...].

Me defiendo. Y me defiendo porque vivo de la pluma, y porque he sufrido mucho hasta lograrlo, y porque con ella he dado de comer a los que me han rodeado, porque tengo una hija cuya felicidad futura he de edificar a fuerza de plumazos, y porque un hombre como yo, que ha sido verdadero hombre frente a la vida y frente a la adversidad y frente

1. La carta está fechada «en los últimos días de diciembre» de un año indeterminado, aunque por su contenido se deduce que está redactada en torno a 1928. A ella se refiere Mihura en una de las entrevistas concedidas a Emilio de Miguel (1997). Julián Moreiro (2004: 83-85) cita un breve fragmento en su imprescindible biografia del dramaturgo. (Debo agradecer a Doña Carmen Ruiz Villandiego la consulta del legado de los hermanos Mihura en Fuenterrabía, donde se hallan esta carta y la mayoría de los documentos que voy a citar). (1973).

2. Nadie mejor que Orson Welles ha sabido poner en jaque este mito en su película Fraude 
a mil dificultades de todo género, está en la obligación ineludible de defenderse contra los «amateurs» de la literatura que, tranquilos, sin preocupaciones materiales, con las espaldas resguardadas por la vida fácil, intentan pisarles el terreno, convirtiendo una labor abundante y diversa de años enteros en falsilla literaria para unos cuentos artículos y cuentos que, ante la inconsciencia de un lector nuevo, pueden significar tanto como lo otro.

Cuida, pues, tu trabajo en lo futuro. Soy tan risueño que a mí mismo me da miedo perder mi risa. Y soy tan escéptico que por defender mi ingenio -único patrimonio de mi hija, que es lo único en que creonada habrá que me detenga. Creo que tienes derecho también tú; vive de él, pero no te salgas de tus fronteras, porque el Derecho Internacional lo prohíbe.

Me ha parecido oportuno reproducir parte de esta carta porque permite reconstruir un momento significativo de la historia interna del grupo. En este sentido, me llama la atención la enorme laguna existente en el ámbito de la correspondencia privada entre sus miembros. Cuando nos desbordan las ediciones de epistolarios de los poetas del 27 -Diego, Guillén, Salinas, Cernuda, Larrea-, entiendo que el discreto conocimiento que aún tenemos del grupo de los humoristas se debe en buena parte a que sólo se ha producido una exhumación mínima tanto de epistolarios como de otros documentos que podrían contribuir a dibujar el contexto apropiado en el que se insertan las obras. En las páginas que siguen presento algunos datos hasta ahora inéditos que espero nos ayuden a entender con mayor exactitud los dos grandes proyectos periodísticos en los que participó Miguel Mihura antes y después de la guerra civil: $L a$ Ametralladora y La Codorniz.

\section{La Ametralladora (1937-1939)}

El 12 de febrero de 1939, poco antes de que La Ametralladora se despidiera de sus lectores, el joven redactor-jefe Álvaro de Laiglesia escribe un reportaje de dos páginas en el que desvela las interioridades más destacadas de la redacción. El artículo, ilustrado con fotografías de los humoristas, es toda una astuta maniobra publicitaria de su director, Miguel Mihura. Aquellos autores que se habían encargado de la parte propagandística, esencial en sus inicios, son silenciados en una coda final: «Y está Guillén Salaya, el popular escritor, que con Estany Serra nos hace los artículos doctrinales y las consignas. Y Valdivielso, que aunque ahora trabaja 
poco para nosotros, ha sido uno de nuestros más respetados y queridos redactores»).

Para entender la importancia de este viraje hay que remontarse dos años atrás, a comienzos de 1937, cuando nace en Salamanca la Delegación del Estado para Prensa y Propaganda, dependiente de la Secretaría General del Estado. Esta Delegación será la encargada de crear el 18 de enero de 1937 La Trinchera, semanario destinado a los combatientes del bando nacional, bajo la dirección de Rogelio Pérez Olivares. A partir del tercer número la revista cambia el nombre de su cabecera y pasa a llamarse $L a$ Ametralladora ${ }^{3}$. Se trata de unas hojas toscamente impresas, con escaso material gráfico, y que se amoldan claramente a los requerimientos de la propaganda de guerra: repetición de consignas, discursos, conmemoraciones, desfiguración de los hechos, maniqueísmo y ridiculización del enemigo a través de la invectiva. Todo se subsume en un pathos agresivo, en lo que Angenot (1982) ha denominado retórica de la injuria. Los elementos dialécticos se reducen al mínimo, puesto que el receptor comparte la tesis. El enemigo es atacado a todos los niveles: aspecto físico, actos e ideas. Estamos frente al dominio de una palabra hiperbólica y visceral. El 8 de febrero de 1937 aparece un texto anónimo en la sección «Retratos al aguafuerte». El título es elocuente de lo que vengo anotando: «iYo te maldigo, Pasionaria!»:

Eres el pajarraco nocturno de la revolución. Como los cuervos, te ciernes en el aire, enlutada y terrible, antes y después de las matanzas: en las ciudades, en los pueblos, en las carreteras, en el campo húmedo aún de sangre, cubierto aún de cadáveres. Te preceden las antorchas de los incendiarios, envolviéndote en un humo fétido y asfixiante. Ante tus ojos desfilan los templos profanados, las imágenes sacrílegamente descuartizadas, los hogares saqueados, forzados su tierno secreto doméstico.

¿Cómo es posible entonces que Miguel Mihura, dibujante y colaborador en revistas de humor, hombre tímido nada dado a exaltaciones patrióticas, se convirtiese en el director de un semanario bélico? Mihura sale de un Madrid republicano que le desagrada y se instala San Sebastián una vez que los nacionales toman la ciudad. Gracias a su situación estratégica y a sus modernos talleres de impresión, San Sebastián se había converti-

3. Los redactores argumentan que el cambio se debe a que los rojos habian plagiado el nombre. En la Hemeroteca Municipal de Madrid figura, en efecto, con el título de La Trinchera un Boletín del Frente Moncloa impreso entre 1936-1938 en la Gráfica Socialista. 
do en una auténtica capital cultural en la que se daban cita los artistas e intelectuales que no comulgaban con el ideario de la República (Ascunce, 1999). El carné de afiliación falangista de Mihura data del 16 de marzo de 1937 [Fig. 1], es decir, menos de un mes después de su llegada a San Sebastián por la frontera de Irún.

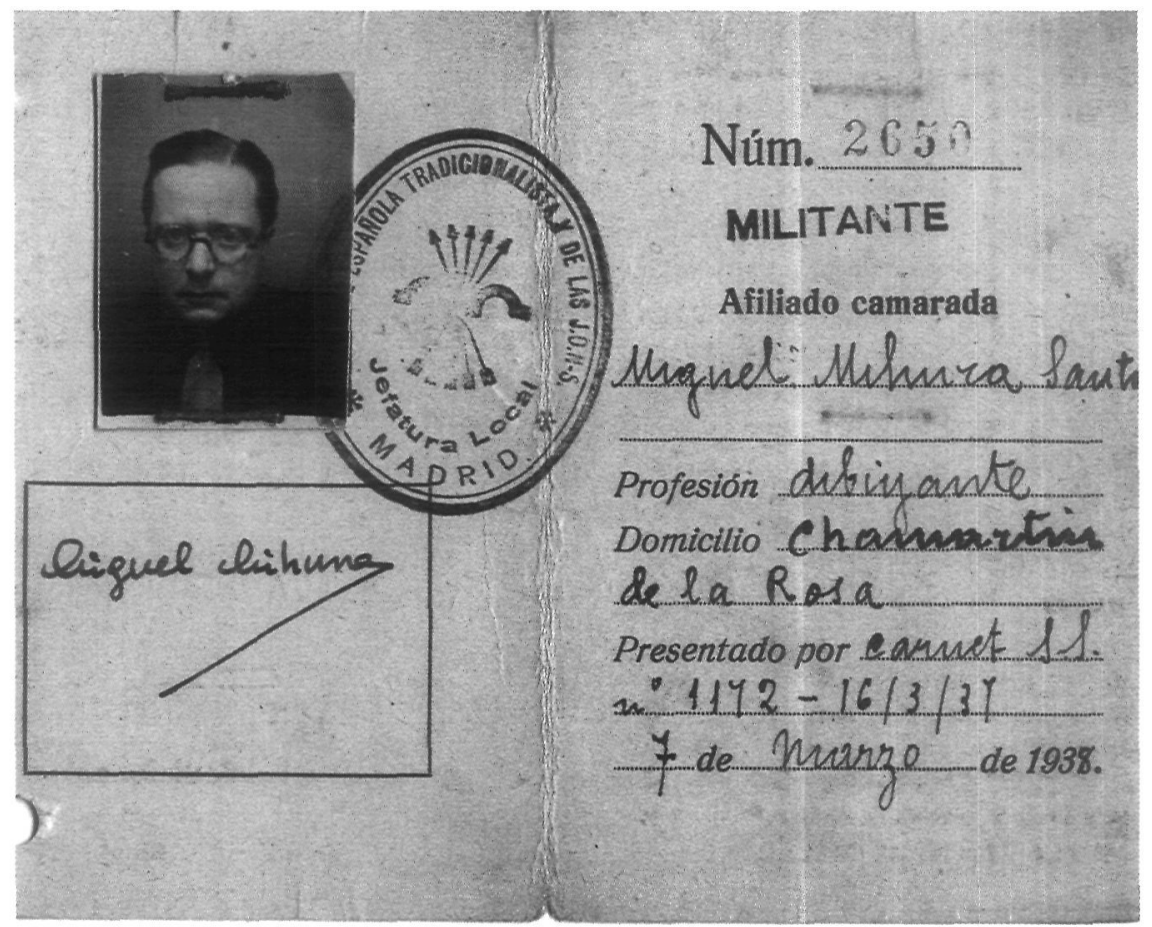

Fig. 1. Carné de militante de Miguel Mihura. Archivo de Fuenterrabía

El propio Mihura (2004: 1367) ha contado su peripecia. En San Sebastián empieza a colaborar en Vértice, donde firma con el pseudónimo de Lilo. Su estilo lo reconocen en la Delegación de Prensa y Propaganda; piensan que por su experiencia sería el director idóneo para La Ametralladora, así que lo citan en Salamanca en mayo de 1937. En ese momento, el semanario se estaba editando en Valladolid. Imaginemos su estupor primero, sus dudas, sus nervios en el largo viaje en tren. A buen seguro le entristeció hojear aquel rudo folleto que le pusieron delante para que él lo dirigiese. No es esto, no es esto. Pero eran tiempos de supervivencia y a él, gran egoísta, siempre le gustó la buena vida. Difícilmente podía negarse. 
El primer documento del que tenemos constancia en el archivo de Mihura en Fuenterrabía es una carta fechada en Salamanca el 4 de julio de 1937 que le dirige Joaquín Borrás en nombre del Delegado Nacional de Prensa y Propaganda, Manuel Arias-Paz. Esta carta demuestra la confianza total que tenían en Mihura, ya que acceden a todas sus peticiones: un jugoso sueldo (750 pesetas), salvoconducto, traslado de su hermano Jerónimo a la ciudad donostiarra, material fotográfico a voluntad y prensa humorística extranjera, circunstancia que refrenda la temprana relación de Mihura con los humoristas italianos. En una carta posterior firmada por Arias-Paz constatamos un hecho relevante. En realidad, la dirección era compartida: él se ocupaba de la dirección artística, mientras que Tomás Borrás llevaba la parte propagandística. Esta bicefalia dice mucho de las reservas que abrigaba Mihura hacia un compromiso político firme y explica bastante la esquizofrenia que marcará la evolución del semanario.

Ese mismo verano los nacionales ocuparon Bilbao y Santander. ¿Cómo hacer humor en medio de la masacre? La Ametralladora seguía dando cabida a versos heroicos, parodiaba la prensa roja, introducía reportajes sobre la barbarie comunista y daba cabida a la voz del soldado en una sección como «Fuego graneado» ${ }^{4}$. Nietzsche, padre de la sospecha, lo supo: valores metafísicos como la verdad o la justicia son máscaras de la voluntad de poder. En una guerra más que nunca. Las primeras colaboraciones de Mihura están datadas el 16 de mayo de 1937, en el $\mathrm{n}^{\circ}$ 18. Como haría después Roberto Begnini en La vita è bella, Mihura introduce la peonza del humor y del juego en el territorio de la tragedia. En uno de sus chistes gráficos la esposa le regaña al marido: «-Ya te he dicho cincuenta veces que no quiero que vayas a la guerra. Luego vuelves con el traje lleno de manchas». Atenuación naïf cuando en el frente está cayendo la metralla encima del papel. En la sección «Cuentos para caballos» del mismo número, Mihura publica un relato breve que insiste en la ficción antirrealista y en el absurdo a través de la historia del doctor Ivory, que se ha enriquecido hasta el punto de poder comprarse un enfermo para su propio uso y disfrute. El mínimo argumento sigue la poética vanguardista deshumanizada que expuso Ortega en célebre ensayo de 1925: triunfo de las formas desencarnadas de la realidad cotidiana, exaltación de la puericia:

4. Para mayor información acerca de las secciones y de su contenido, aspectos en los que no me voy a detener demasiado, remito al lector a los trabajos de Emilio González-Grano de Oro (1980), Félix Maraña (1990), José Ángel Ascunce (1999: 210-220) y José Antonio Llera (2000). 
Las visitas le miraban por todas partes, levantando el mosquitero, y lo encontraban muy barato, y después decían que con aquel enfermito, en aquel rincón, la sala resultaba mucho más mona. $Y$ todos se sentaban a su alrededor y le echaban bromoquinina.

Esto hacía perder mucho tiempo al doctor. Y como además no dejaba de estudiar desde por la mañana hasta por la noche muchos libros gordos para saber curar a los enfermos, resultaba que no le quedaba lugar ninguno para curar a los enfermos, ni para verlos siquiera, ni para nada.

[...] La gruesa esposa del doctor salía con una bata rosa con ramos y le miraba el vientre por un lado y por otro al viejo caballero y se lo empujaba con un dedo, al mismo tiempo que saludaba a los vecinos que subían y bajaban por las escaleras [...].

-Usted no tiene nada, caballero - aseguraba la señora estupenda-. Eso son manías.

-Bueno, pues adiós y muchas gracias.

-Adiós, guapo.

Y el viejo caballero se iba tan avergonzado que al llegar a casa no tenía más remedio que pegarse un tiro.

Nada más y nada menos que un suicidio; el tema que será barrido de cualquier publicación en cuanto se implante la censura previa en 1938. En el cuento sólo es el lema de una violencia descontextualizada e inverosímil.

El $\mathrm{n}^{\circ} 23$ será el primero en que Mihura asuma la dirección de $L a$ Ametralladora, que se imprime en color y en offset en los talleres Necerán de San Sebastián, con una tirada próxima a los cien mil ejemplares. Me llama la atención la nota editorial: «Hemos cambiado el trípode, hemos renovado algunas piezas y sustituido el peine por la cinta. En total, más alcance y más eficacia, entendiendo por tal la mejor distracción del combatiente, para quien es, en primer lugar, nuestro periódico». Distracción frente a instrucción. Evasión frente a adoctrinamiento. No se sustituye un factor por el otro (imposible en una publicación que pertenece al engranaje de la propaganda), pero por vez primera se ponen de relieve los factores catárticos asociados a lo cómico, lastrado hasta entonces por la sátira ad hominem y por la bilis negra ${ }^{5}$. Uno de los testimonios más antiguos que

5. En la misma página en que Mihura escribe su relato, se halla otro texto sin firma de un contenido e intención radicalmente opuestos. Se trata de la biografía satírica «José Antonio Aguirre, presidente de la República de Euzkadi». El final no necesita comentario: «Esta biografia debiera terminar con la muerte de Aguirre. Desgraciadamente para nosotros y, sobre todo, para Vizcaya, es incompleta. Pero los bacilos nunca han sido longevos, afortunadamente, y menos cuando se lucha y se vence para que no lo sean»?. 
alude a la relación entre la risa y la violencia es un pasaje de La República de Platón: «[...] no conviene que los guardianes sean gente pronta para reírse, ya que, por lo común, cuando alguien se abandona a una risa violenta, esto provoca a su vez una reacción violenta» (III, 388e). Tanto la fisiología como el psicoanálisis le llevarían la contraria al filósofo: el humor, en tanto que modalidad que desencadena la risa, atempera las pasiones, le sirve al yo para limar las aristas del mundo. La sutil revolución de Mihura consiste en insertar dentro de la crónica bélica y la intención referencial una veta de ficción y de eutrapelia, un discurso no lineal dentro del código cerrado de la ideología que irá creciendo poco a poco, a medida que los nacionales vayan ganando la guerra y se encuentre más liberado de la urgencia doctrinal. Un mundo deformado lúdicamente, un refugio inocuo frente a la realidad externa de la violencia y de la sangre. El absurdo que irá ganado cada vez mayor espacio en La Ametralladora representa un delirio ficticio en medio de un delirio real. El universo semiológico de las ideologías totalitarias actúa mediante hipercodificaciones, nociones universales borrosas y fuertes dicotomías. Al contrario, el humor nuevo de herencia ramoniana que se gesta en Buen Humor y en Gutiérrez recurre a un sinsentido universal que atraviesa la historia del ser humano. A través del cambio de perspectiva y la ironía renuncia al patetismo voraz de la propaganda.

¿Humor puro en una revista de propaganda? Naturalmente había que compensarlo con ciertas concesiones al presente; era imprescindible también orientar ideológicamente el humor. Está documentado que Mihura acudía al refrito de textos propios editados anteriormente en Gutiérrez para llenar las páginas de La Ametralladora (González-Grano de Oro, 2004: 369-397). Para pasar la aduana, bastaba con introducir algún indicio circunstanciador, que a menudo se desvanecía en una ilustración infantiloide y geométrica. Con Mihura ni mucho menos terminan las consignas ni los contenidos doctrinales, pero lo que sí es cierto es que se van aceptando los códigos de la propaganda no para endurecerlos sino para liberar tensiones y rebajar la agresividad. Lo fácil hubiera sido renunciar a su estilo, pero siguió dibujando monigotes y rechazó la distorsión figurativa de la caricatura. Un ejemplo de lo que digo es una de las secciones que inventa: «El carnaval de los animales», donde se ridiculiza a los políticos y a los mandos militares republicanos. Compárese este cuarteto satírico (mala literatura, claro) contra la Pasionaria con el fragmento que citábamos más arriba, en el que también está presente la degradación zoomórfica: «-Cesa ya tu mugido quejumbroso, / vaca fofa, trotona y sin enmienda. / No te acerques a mí, sigue tu senda, / que ya escucho el cencerro de tu esposo») 
(25-VII-1937). El soneto lo firma Martín Somoza y lo ilustra Lilo con una oronda vaca que parece arrancada del cuaderno de un niño.

Secciones satíricas como «Las aleluyas», parodia de los retablos de ciego enderezadas contra políticos como Azaña o Stalin, así como aquellos apartados reservados para el rumor o la anécdota sañudos, conviven en una mezcla imposible con los «Diálogos estúpidos», «Las caricaturas requisadas», «El espaso» de Tono y las greguerías de Neville: «La oveja es como un pedazo de almohada con un perro dentro; y ese tener lana por todas partes es lo que les produce a las ovejas tanto sueño» (30-IV1939). Mihura no tenía desde luego las manos libres y muy pronto recibe «sugerencias» en cuanto a la línea editorial. En noviembre de 1937, la Delegación envía a San Sebastián un redactor-jefe, Juan Brasa Sánchez, que había sido director de España de Hoy y que firmaba con el pomposo pseudónimo de El Legionario de la Pluma. Pedro Gómez Aparicio, Jefe de la Prensa Nacional, le concede a Mihura un aumento de sueldo (ahora 1000 pts.) y aprovecha para hacer el pertinente dirigismo ideológico:

A mi juicio La Ametralladora puede convertirse en algo así como un órgano de fusión entre los frentes y la retaguardia, para lo cual conviene mucho que explique a los lectores de la retaguardia mediante crónicas del parapeto, fotografías, etc., cómo viven nuestros soldados y a su vez constantemente a nuestros combatientes, también mediante reportajes sobre las distintas obras de carácter benéfico, social, etc., la sensación de que en la retaguardia hay todo un pueblo que piensa en ellos y que en todo momento les asiste.

Al terminar de leer la carta, Mihura debió de encogerse de hombros. No había manera de que le dejasen hacer una revista de humor, literaria. Las palabras de Gómez Aparicio no podían caer en saco roto. El gobierno republicano se acaba de trasladar de Valencia a Barcelona, y pronto comenzaría la batalla de Teruel. Pero si echamos una ojeada a La Ametralladora se observa que Mihura mantiene los contenidos humorísticos y que las demandas típicamente periodísticas -luego propagandísticas- de Gómez Aparicio van a satisfacerse sólo a medias.

Entre los papeles de Fuenterrabía se encuentra una carta fechada el 24 de noviembre de 1937 y dirigida a Manuel Arias-Paz. El incidente va a poner a prueba el carácter de nuestro autor. La carta es reveladora de una lucha de poder provocada por la división -y la presumible falta de comunicación- entre Borrás, encargado de supervisar lo estrictamente ideológico, y Mihura. Éste logra resolver el altercado a su favor con la incorporación de un nuevo redactor-jefe menos advenedizo, José Simón Valdivielso, antiguo redactor de El Heraldo de Madrid y de Informaciones: 
El día 11, jueves, llega el Sr. Brasa a esta Redacción, habla con el Sr. Borrás y con gran sorpresa mía el Sr. Borrás le hace entrega de originales artísticos y literarios, le pone al corriente de todo, y le presenta a los amigos y colaboradores «como el nuevo director de La Ametralladora». Y el Sr. Brasa acepta el nombramiento que le hace el Sr. Borrás.

Yo entonces me veo en la obligación de aclarar aquello y hago constar la conferencia telefónica que tuve con el Sr. Aparicio en la que se me había dado la dirección del periódico.

Esta aclaración parece molestar al Sr. Borrás tanto como al Sr. Brasa y da motivo a una discusión desagradable en la que yo solo trato de aclarar el puesto de cada uno. En realidad, parece que mi nombramiento no es demasiado bien acogido.

[...] El lunes llega [el Sr. Brasa] al medio día para decirme que insiste en marcharse. Y se marcha. Y yo solo entre la tarde del lunes y el martes, tengo que hacerme todo el periódico.

Afortunadamente, el Sr. Valdivielso empieza a ayudarme desde el miércoles y me dice que en iguales condiciones que el Sr. Brasa él ocuparía el puesto de redactor-jefe. Como me parece un hombre indicadísimo para este puesto, y como su ayuda es eficaz, pongo un telegrama al Sr. Aparicio, proponiéndole a Valdivielso para que sustituya a Brasa.

Caso cerrado. Valdivielso demostrará su ardor guerrero en más de una parodia de la prensa roja, mientras Mihura y su equipo (Enrique Herreros se incorpora en el $\mathrm{n}^{\circ} 80$ ) continúan con la idea de un humorismo que toca la entraña misma de la comedia, esto es, «una constante distancia interna con respecto a lo que allí se está presentando» (Martínez Marzoa, 2005: 39-40). Había que mantener las formas, de modo que si la portada es humorística, la contraportada deberá amoldarse a las leyes de la propaganda, como demuestra el cartelismo grandilocuente de Aróztegui. De vez en cuando, un chiste gráfico de Tono de sabor político, pero ilustrado de tal modo que se rebaja la pulsión hostil. Hablan dos enamorados:

$-¿$ Y si diéramos un paseo?

-¿A quién? (19-VI-1938)

En abril de 1938 Serrano Suñer crea la Ley de Prensa. Desde la Subdelegación del Estado para Prensa y Propaganda de Guipúzcoa se reciben ese mismo mes en la redacción de La Ametralladora las primeras consignas. Salta a la vista el sesgo nacional-católico que será la seña de identidad del aparato censor durante la primera posguerra: «Se prohíbe atacar en absoluto a la Santa Sede y en general toda afirmación que pueda ser molesta para el Vaticano. En la información militar tanto gráfica como literaria deberá ser evitada la personalización caprichosa». Esto debió de 
sacar de quicio a Mihura en más de una ocasión, a juzgar por la carta que dirige el 2 de septiembre de 1938 a su Jesús Ercilla, nuevo Director General de Prensa:

Te envío urgentemente las fotografías y textos que la censura civil de aquí nos ha tachado.

Como creo que se trata de una represalia de tipo personal motivada por el incidente que tuvimos en números anteriores y como a mi entender no hay razón para tacharnos esos textos y esas fotografias, alguna de las cuales ya se han publicado otra vez en nuestra revista, te ruego que tomes las medidas necesarias para que no exista esta saña contra nosotros pues de seguir así, yo no me comprometo de ninguna manera a seguir haciendo La Ametralladora.

[...] El incidente ocurrido en números pasados ha sido verdaderamente doloroso, pero si de aquí en adelante y con motivo de él, existe esta especie de desconfianza con La Ametralladora, y los señores encargados de la censura ven un doble sentido o una mala fe en todo lo que publiquemos yo, como te digo, me creo incapaz de sostener esta lucha infantil.

Es comprensible que los censores se sintieran desconcertados al revisar las páginas de un semanario en el que la necesidad histórica de la tragedia cohabitaba con la ley arbitraria de un humorismo cada vez más enajenado de la realidad. Pero ¿quién era Jesús Ercilla? Ercilla, médico psiquiatra, fue el hombre de confianza del falangista Onésimo Redondo en Valladolid, donde fundó en 1931 el diario Libertad. En junio de 1938 es nombrado redactor-jefe de La Ametralladora, cargo que ostenta sólo unos meses. En su sustitución llega el joven aprendiz de humorista Álvaro de Laiglesia, procedente del semanario infantil Flecha ${ }^{6}$. La amistad con Ercilla volverá a ser clave para que la Dirección General de Prensa le concediera a Mihura la autorización administrativa para poder publicar el primer número de La Codorniz el 8 de junio de 1941.

Ganada la guerra por el bando nacional, La Ametralladora edita su último número el 21 de mayo de 1939. Como se deduce de un diálogo ficticio entre la publicación y su lector, Mihura tenía la idea de seguir con un proyecto nuevo: «Quizá vuelva. Pero a lo mejor me presento ante ti cambiada. Iré vestida de otra manera. Te contaré otras cosas distintas. Tendré otra sonrisa aún más joven». Creo que, en realidad, la auténtica

6. Cfr. Las páginas memorialísticas de Álvaro de Laiglesia (1974: 959 y ss.), en las que relata cómo conoció a Mihura. 
propaganda realizada por Mihura en La Ametralladora fue la de una tendencia humorística que triunfaría plenamente durante la posguerra.

\section{La Codorniz de Miguel Mihura (1941-1944)}

Tanto Mihura como Tono ya habían pagado su canon al nuevo régimen franquista publicando en noviembre de 1939 en «La Novela del Sábado» María de la Hoz, su particular sátira del Madrid rojo (Moreiro, 2004: 184-187; Ríos Carratalá, 2005). Así como La Ametralladora fue en muchos casos una reescritura politizada de textos aparecidos en Gutiérrez, La Codorniz será una reescritura purificada de los textos aparecidos durante la guerra, hecho que evidencia la continuidad de la poética vanguardista de los años veinte (Llera, 2001). Esa reescritura pasa por la afluencia ya sin trabas de una literatura y de un grafismo con el sello del arte autónomo, liberados de la servidumbre a la invectiva y a la caricatura personalizada. Mihura lo rememoraba al cumplirse el vigésimo quinto aniversario de La Codorniz: «La Ametralladora es una revista de guerra, yo quiero que el título de esta nueva publicación signifique todo lo contrario [...]. Por ejemplo, el nombre de un pájaro o de un ave. Algo que refleje inocencia y buena intención. Y así surge el título de La Codorniz». Creo que cuando nuestro autor redacta el capítulo «Periodismo de humor» para la Enciclopedia del periodismo de Nicolás González Ruiz no sólo alude en las primera líneas a la prensa festiva y satírica, sino que hace autocrítica de ese humor de pie forzado que publicó él en La Ametralladora:

Hay que reconocer que el periodismo cómico en España ha sido siempre bastante pobre y cochambroso y se ha nutrido durante muchos años de chascarrillos baturros, de cuentos andaluces, de gracia de mal gusto y de insolente intención política (Mihura, 2004: 1292).

Uno de los personajes-fetiche de La Codorniz, como antes lo fue de La Ametralladora, será Don Venerando. El padre del personaje no es otro que el humorista italiano Carlo Manzoni, por mucho que Mihura y sus colaboradores jugaran al despiste sobre este asunto. En el reportaje de Álvaro de Laiglesia ya citado se lee lo siguiente: «El autor de don Venerando, de doña Carolina y don Trinitario, es Rafael de Vega. Vega es un hombre modesto que envía sus originales con un chico o me los da a mí en el café mientras juega su partida de dominó»?. En realidad, lo que hacía Vega era adaptar o traducir el original italiano, práctica que Mihura continuará en La Codorniz hasta principios de 1943 en que viaja a Milán para entrevistarse con los humoristas del Bertoldo y solucionar el problema 
de los derechos de autor. Algunas explicaciones posteriores ${ }^{7}$ en el sentido de que desconocía la autoría de los relatos resultan inverosímiles, ya que consta que él mismo solicitó durante la guerra diversas revistas de humor extranjeras a la Delegación de Prensa y Propaganda. Sea como fuere, es cierto que el Don Venerando de Manzoni enlazaba con temas y motivos humorísticos que la otra generación del 27 venía cultivando en publicaciones de los años veinte, así como con las obras tempranas de Gómez de la Serna. Por cierto, ¿qué sería de su amigo Ramón en el exilio de Buenos Aires? ¿Pasaría las horas acariciando las medias de Luisa Sofovich y acordándose de Pombo? Le pediría textos para La Codorniz. Le pagaría bien.

Como he estudiado en otro lugar (Llera, 2003: 50-60), la predilección de La Codorniz por las situaciones disparatadas se cifra en el extrañamiento cómico que produce en el lector tanto el espectáculo de una lógica invertida como el naufragio de los principios pragmáticos de la conversación. Veamos un ejemplo extraído del no 4 de La Codorniz (29-VI-1941), donde el absurdo ficcionaliza lúdicamente un tema serio como la guerra. Arthur Koestler (1964: 35) hablaba de bisociación para estos casos en que se perciben dos marcos de referencia generalmente incompatibles dentro de un mismo contexto:

Don Venerando logró acercarse, sin ser visto, a un tanque inglés. -¡Eh! - gritó cuando ya estaba cerca-. ¡Eh! ¡Usted! ¿Está libre? - ¿Cómo? gritó el soldado inglés sacando la cabeza por la trampa del tanque y sorprendido por la pregunta.

-Pregunto si está usted libre -dijo don Venerando-. Busco un automóvil.

-Esto es un tanque -balbució el soldado inglés, confuso.

${ }_{-}$¿Y un tanque no es automóvil? -preguntó Don Venerando, extrañado-. Yo creía que los tanques eran automóviles. Pero si no son automóviles, ¿entonces qué son? No estoy muy al corriente de los nuevos tanques. ¿Acaso es éste una alcachofa?

El proyecto de La Codorniz puede resumirse en la lucha contra toda clase de estereotipo, ya sea lingüístico, literario o moral. De acuerdo con

7. Véase un fragmento de la carta que le dirige a Emilio González-Grano de Oro (2004: 390), en la que se excusa diciendo desconocer que los relatos fueran de Manzoni. Algo parecido le cuenta en carta personal al periodista navarro José Javier Fuentes (apud Moreiro, 2004: 194). No será la última vez que se plantean problemas con el copyright, ya que durante la época en que La Codorniz estuvo dirigida por Álvaro de Laiglesia se llegaron a reproducir sin previa autorización chistes gráficos del New Yorker. 
Barthes, el estereotipo puede ser evaluado en términos de fatiga. La repetición engendra pereza mental. Los formalistas rusos habían definido el lenguaje poético en términos de desautomatización, mientras que Eugenio Coseriu (1977: 75) hablará de una actividad cognoscitiva caracterizada por la continua re-creación. Las fraseologismos y los refranes, paradigmas de la queratinización del lenguaje, son alterados e invertidos de continuo en los textos de Tono, mientras que Mihura y Neville imitan los hallazgos metafóricos de Ramón en sus greguerías. La parodia se ceba en subgéneros cómicos entonces muy en boga -la alta comedia y la comedia de costumbres-, socava los dramas de la tradición áurea y ridiculiza el patetismo del folletín romántico. Un humor que le da la vuelta a todo, que ve el mundo en perpetua transformación, lejos de los ideales doctrinarios de la identidad y el mesianismo. Darle la vuelta a todo, incluso a la terrible frase de Hegel, que dictaminaba que lo real es lo racional. No. Lo irracional también es real, aunque se oculta en una esquina más invisible, más a trasmano. Me he referido también a los estereotipos morales, que no son otros que los que supura la burguesía. Mihura, gran burgués, los mira de reojo, con autoironía: las visitas, el veraneo al borde del mar, el matrimonio, los manuales de urbanidad, etc. Aunque Mihura siempre lo negara, en La Codorniz hay lugar también para la sátira realista, que viene a problematizar la poética deshumanizada en que se apoya el semanario. Con la elección de un autor como Wenceslao Fernández Flórez se pretendía prestigiar la cabecera con la firma de un autor consagrado de la generación novecentista. El autor gallego será autor de relatos y de columnas de un incisivo humor costumbrista que seguramente era tolerado porque ya había pagado su bula escribiendo la novela autobiográfica Una isla en el mar rojo (1939).

Uno de los aspectos en los que se observa un salto cualitativo relevante respecto de La Ametralladora es en la nueva maquetación. Ilustraciones, chistes gráficos y fotografías se distribuyen a mayor escala y se introducen orlas - Herreros es su autor- que individualizan cada colaboración. El éxito de La Codorniz fue fulminante. Esto no quiere decir que no tuviera sus detractores. En un contexto sociocultural timorato y solemne, donde imperaba un estirado nacionalcatolicismo, ciertos lectores no entendían la debilidad de un ilustrador como Picó por las lolitas en bicicleta. Entre los papeles de Mihura en Fuenterrabía se halla una carta firmada por un tal Gabriel Larreta en la que con un estilo episcopal amonesta al director de La Codorniz por sus deslices:

Entre los muchos y variados encantos que tiene ese semanario, no es el menor el de su limpieza moral, sin que para conseguir el aplauso del 
público tenga que recurrir, como las cupletistas baratas, a suplir el arte con la desvergüenza.

Si así es, si el éxito de La Codorniz está en toda ella [...] ¿quiere decirme a qué viene en su último número esas dos señoritas que para ser guapas no hace falta que nos enseñen las piernas hasta más arriba de las fronteras que marca la moral?

No sea Vd. vulgar, Sr. Mihura; siga triunfando con su ingenio a través del lápiz y la pluma [...]. No descienda a ese nivel.

La foto es célebre. Visten capas sobre el uniforme militar, el cuerpo rígido, la barbilla levantada en actitud extática. Franco y Millán Astray cantan el himno de la legión durante el acto fundacional. Después, comenzada la guerra, Franco pondría a Millán Astray al frente de la Delegación del Estado para Prensa y Propaganda. Fue una especie de Goebbels de barraca. Nadie lo diría: descubrimos que aquel que arengaba a sus legionarios al grito de jviva la muerte!, quien en un acto académico en la Universidad de Salamanca regurgitó sobre Unamuno el bárbaro jmuera la intelectualidad! era también lector de La Codorniz. La carta conservada en el archivo de Fuenterrabía, con el membrete del Cuerpo de Mutilados de Guerra, lleva fecha de 23 de agosto de 1943, y está dirigida al director, los redactores y los dibujantes:

Queridísimos amigos míos:

Esta carta, que es privada y particular para vosotros, os la envío en muestra de profunda gratitud para todos los que hacéis La Codorniz. He de deciros que mi mujer, Elvirita, está esperando el sábado para entrar triunfalmente y contenta en mi cuarto a traerme La Codorniz, que la leo como se comen los chiquillos los pirulís, o sea, poco a poco y riéndome. ¡Fijaos bien lo que es para cualquier hombre y para un hombre de tan azarosa vida y de tanto dolor el reírse francamente a mandíbula batiente!

Estoy admirado de los dibujantes o pintores de esas planas grandes a todo color y me he congraciado con esos muñecos de los ojos en no sé dónde y las barbas hebraicas. Y los chistes, y las salidas de tono, de Tono, y la originalidad vuestra y en fin... todo, todo. [...]

LO QUE NO ME GUSTA:

Empiezo por lo que no me gusta y así quitar el amargorcillo de la crítica, no censura, y que quizás sea, y seguramente lo será, equivocada, ya que los de La Codorniz, por hacerla y por vuestro éxito demostráis palpablemente que de eso sabéis más que todos los demás. No me gusta -y resulta ya pesado- esa historia siempre igual de lo que hicieron los asirios y los fenicios, que descubrieron las cosas que descubrieron. Es siempre igual y ya basta [...]. 


\section{LO QUE MÁS ME GUSTA:}

Me gusta todo: el chiste, la portada, la contraportada -o como se llame, que no lo sé-; las preguntas que hacéis de orden cultural, que son interesantísimas y se siente una gran alegría cuando adivina uno muchas, y se da cuenta de lo poquito que sabe cuando se queda la mayor parte sin adivinar ${ }^{8}$; las historietas de ese rey pequeño son maravillosas.

Las armas y las letras. No creo que fuera consciente de la ironía de efecto retardado que minaba su carta: un mutilado de guerra, que en una batalla perdió un ojo y parte de la dentadura, confiesa que ríe «a mandíbula batiente». Estamos ante una imagen humorística de excepción: el viejo guerrero infantilizado que comulga con la risa curativa. Con esta lectura superficial del semanario le bastaba. Calificar a La Codorniz como una revista reaccionaria a causa de su humor evasivo equivale a consagrar un tópico de tanta magnitud como el de atribuir a Mihura una intención subversiva contra el statu quo franquista. Esta dicotomía no nos sirve. El humor codornicesco se rebela contra todo tipo de formas esclerotizadas, sean literarias o morales. Su ambigüedad radica en que si bien no persigue una corrección al modo de la sátira y se sitúa en un marco ficticio deshistorizado, el reflujo irónico que recorre sus textos es propio de una obra abierta. La pasión por lo disparatado nos dice que no existe un sentido único, que toda visión del mundo es borrosa en su naturaleza, que por encima de la lógica y el orden persisten el equívoco y la sombra. Ramón Gómez de la Serna, en ese mínimo evangelio que es «Humorismo», ya lo advertía: «Cuanto más confunda el humorismo los elementos del mundo, mejor va» (1975: 199). Mejor va ¿qué? La ambigüedad tal vez sea deliberada: el humor o el mundo, el mundo y el humor.

Una vez que la Dirección General de Prensa le concede el 7 de abril de 1941 la autorización administrativa para editar La Codorniz, Mihura se plantea cuál sería la empresa editorial más conveniente para llevar a cabo su proyecto. Elige Sucesores de Rivadeneyra, de la que era director-gerente su amigo Manuel Halcón. Ese mismo mes llegan ambos a un

8. Millán Astray alude a la sección «¿Está usted seguro?», creada por López Rubio. En una carta sin fecha que encuentro en el archivo de Fuenterrabía, éste se queja a Mihura por las libertades que se toma: «Te mando un «¿Está usted seguro?» que te he hecho a pesar de mis trabajos en estos días. No me ha gustado nada que publiques otros hechos no sé por quién, porque es una cosa que quiero hacer yo y porque esos que han salido están muy mal hechos, son muy difíciles y se me ha quejado ya bastante gente». 
acuerdo. Mihura le reconoce a Halcón su derecho a percibir mensualmente el cincuenta por ciento de las utilidades líquidas que se obtengan por todos los conceptos de la revista y conviene que si él decidiera dejar de publicar La Codorniz Halcón podría continuarla. Un año después, en abril de 1942, Mihura formalizará un contrato con el apoderado general de Sucesores de Rivadeneyra. La sociedad impresora y distribuidora controlará a partir de entonces toda la parte administrativa. En contrapartida, el director de La Codorniz percibe un sueldo astronómico (5.000 pts.), cantidad a la que habría que sumar cada uno de los trabajos que firmara en cada número (la empresa fijaba para ellos un tope de $750 \mathrm{pts}$.) y el $40 \%$ de las ganancias por la publicidad. El contrato estaba sometido, como es lógico, a las ventas: «Siendo en la actualidad la tirada de $L a$ Codorniz de 27.300 ejemplares, si la venta disminuyese y por esta causa bajase la tirada hasta 21.300 ejemplares, quedaría anulado el presente contrato [...]. Si por el contrario la venta subiese y la tirada excediese de 33.000 ejemplares, el señor Mihura cobraría un céntimo por cada ejemplar más de los 33.000 , cuyo importe le abonaría mensualmente Sucesores de Rivadeneyra». La tirada, en efecto, aumentó, pero eso no fue óbice para que Mihura se cansara de la revista. Entre las causas que esgrimió para justificar su venta se encuentran tanto el cansancio personal como la creencia de que lo codornicesco se había impuesto como una moda burguesa más. El ingenio de la revista se había vulgarizado. Sin embargo, nunca se refirió públicamente a las desavenencias internas con la empresa, hecho del que tenemos noticia por la copia de una carta dirigida a Manuel Halcón el 11 de febrero de 1944. Es una carta escrita en tono reprobatorio y que dice mucho del carácter individualista de Mihura. Entiendo que estos problemas actuaron como causa precipitante en su decisión de no prorrogar el contrato con Rivadeneyra. Reproduzco un fragmento:

Amigo Halcón:

A mi atentísima carta de fecha cinco de los corrientes, no sólo no has contestado dándome una pequeña explicación a tu desconsiderada e inexplicable actitud, sino que, por el contrario, el día siguiente del incidente, encargaste a tus empleados que tus órdenes, en cuanto al horario de mi secretaria, se cumpliesen sin excusa ninguna, aun entorpeciendo con esto el trabajo y la marcha de la revista que dirijo $[\ldots]$. 
Porque en el contrato que tengo firmado con Rivadeneyra, se especifica bien claramente que yo tendré a mis órdenes un redactor, una secretaria-mecanógrafa y un botones".

Y sin embargo, a pesar de habértelo rogado muchísimas veces, no he conseguido tener en La Codorniz esta secretaria-mecanógrafa a la que tengo perfectísimo derecho, y que según el contrato, yo soy quien debo elegir o proponer.

[...] Estoy decidido a terminar para siempre con todo lo injusto, lo arbitrario y lo descortés que me rodea y que no me deja trabajar tranquilo y con alegría. Mi imaginación y mi fantasía y mi ingenio - del cual vivo- no pueden estar por debajo de un sistema arbitrario de burocracia. [...] Si mi imaginación necesita un gerente, quiero ser yo el gerente de mí mismo, porque seré un gerente con poesía.

[...] No temo que este nuevo disgusto, unido a los que he tenido anteriormente, me lo achaquen a mi carácter. Tengo la conciencia tranquila, y ya puesto en plan liquidación, prefiero hacer mi liquidación total y amplia.

Por lo tanto, te comunico que para los efectos consiguientes que el $1^{\circ}$ de abril, fecha de la terminación de nuestro contrato, La Codorniz dejará de hacerse en Rivadeneyra.

El último número de esta etapa, el 147, anuncia la reaparición de una nueva Codorniz a finales de abril de 1944. El plazo se alarga hasta el 4 de junio, y con un nuevo director: Álvaro de Laiglesia. Si damos crédito a su relato, fue éste último quien convenció a Manuel Pombo Angulo, Juan José Pradera y el Conde de Godó para que le compraran la revista a Mihura (Laiglesia, 1974: 977). La venta se lleva a cabo ante notario [Fig. 2], y por ella percibe la cantidad de noventa mil pesetas. Con el dinero se marcha de vacaciones a Tánger. No creo que se arrepintiera, aunque después, siempre dispuesto a volver a empezar, le rondara la cabeza aceptar la propuesta de dirigir una antigua cabecera como $\mathrm{Cu}$ - $\mathrm{Cu}$, efímera competidora de La Codorniz.

\section{Conclusiones}

Antes de que José López Rubio se postulara abogado defensor de la llamada «otra generación del 27», Jardiel ya había ejercido de fiscal

9. El punto séptimo del contrato que firma con el apoderado de Rivadeneyra, Ignacio Balanzat, es muy claro: «El señor Mihura tendrá a sus órdenes un redactor, la secretaria-mecanógrafa y el botones para recados, a cargo de Sucesores de Rivadeneyra S. A., quien pagará el sueldo de aquellos»». 
contra Mihura en una carta privada en la que le acusa de plagio. Con su ascenso a la dirección de La Ametralladora en 1937, Mihura acepta entrar en la historia de los vencedores, más por comodidad que por compromiso político. Se rodea de un equipo de humoristas -Tono, Neville, Herrerosno para hacer proselitismo ideológico, sino más bien para publicitar un humorismo deshumanizado que se había estado forjando en revistas anteriores a la guerra civil como Buen Humor y Gutiérrez. Con astucia supo mantener su puesto y utilizar a Jesús Ercilla, falangista intachable, de emisario de lujo ante la Delegación de Prensa y Propaganda.

Acabada la guerra, y resuelto a echar tierra sobre un pasado del que no se sentía orgulloso, funda La Codorniz en 1941. Ni subversiva contra los principios fundamentales del régimen ni reaccionaria, sino todo lo contrario. Lo codornicesco se convierte en sinónimo de lucha contra toda clase de convencionalismo, fuera literario o moral. La paradoja llega cuando una poética deshumanizada -su ancestro- triunfa y se hace popular, incluso para el ardor guerrero de Millán Astray, que felicita a los redactores en una carta encomiástica. Cansado de que La Codorniz fuera el último reclamo de la sociedad burguesa algunos de cuyos ritos había ridiculizado y enemistado con Manuel Halcón, director gerente de la empresa editora, Mihura decide vender la publicación. 


\section{BIBLIOGRAFÍA}

Angenot, Marc, La parole pamphlétaire. Contribution à la typologie des discours modernes, París, Payot, 1982.

Ascunce, José Ángel, San Sebastián, capital cultural (1936-1940), San Sebastián, Artes Gráficas Michelena, 1999.

Coseriu, Eugenio, El hombre y su lenguaje. Estudios de teoria y metodología lingüística, trad. de Marcos Martínez Hernández, Madrid, Gredos, 1977.

Eagleton, Terry, Ideología. Una introducción, Barcelona, Paidos, 1997.

FreUd, Sigmund, El chiste y su relación con lo inconsciente, Madrid, Alianza, 1969 [1 $1^{\text {a }}$ ed. 1905].

Gómez de la Serna, Ramón, «Humorismo», en Ismos, Madrid, Guadarrama, 1975 [1 ${ }^{\mathrm{a}}$ ed. 1931], pp. 197-233.

González-Grano de Oro, Emilio, «Miguel Mihura, Tono y la prehistoria del humor codornicesco», Actas del VI Congreso Internacional de Hispanistas, Toronto, 1980, pp. 340-343.

- La otra Generación del 27. El Humor Nuevo español y La Codorniz primera, Madrid, Ediciones Polifemo, 2004.

KoEstler, Arthur, The Act of Creation, Londres, Hutchinson, 1964.

LlerA, José Antonio, «La Ametralladora, precursora de La Codorniz», en Actas del II Congreso Internacional sobre el Humorismo, Pozuelo de Alarcón, Academia de Humor, 2000, pp. 51-65.

- «Poéticas del humor: desde el novecentismo hasta la época contemporánea», Revista de Literatura, LXIII, 126 (2001), pp. 461-476.

- El humor verbal y visual de La Codorniz, Madrid, CSIC, 2003.

López Rubio, José, La otra Generación del 27, Madrid, RAE, 1983.

MARAÑA, Félix, «San Sebastián, centro cultural y editorial durante la guerra. La Ametralladora y otras publicaciones», en Comunicación, cultura y politica durante la II República y la guerra civil, Bilbao, Universidad del País Vasco, vol. I, 1990, pp. 193-206.

Martínez MarzoA, F., El saber de la comedia, Madrid, Antonio Machado Libros, 2005.

Miguel Martínez, Emilio de, El teatro de Miguel Mihura, Salamanca, Ediciones de la Universidad de Salamanca, 1997 ( $2^{\mathrm{a}}$ ed. revisada).

Minura, Miguel, Prosa y obra gráfica, ed. de Arturo Ramoneda, Madrid, Cátedra, 2004.

Moreiro, Julián, Miguel Mihura. Humor y melancolía, Madrid, Algaba Ediciones, 2004. 
Ortega y Gasset, José, La deshumanización del arte y otros ensayos, Madrid, Ediciones de la Revista de Occidente, 1970 (10ª ed.).

Pizarroso Quintero, Alejandro, Historia de la propaganda. Notas para un estudio de la propaganda politica y de «guerra», Madrid, EUDEMA, 1990.

Platón, La República, trad. de José Antonio Míguez, Madrid, Aguilar, 1963.

Ríos Carratalá, Juan A., «La guerra de los humoristas», Quimera, 257 (mayo, 2004), pp. 18-22.

- «Miguel Mihura también fue a la guerra, aunque poco», en Miguel Mihura cumple un siglo. Actas de las Jornadas en homenaje al humorista y dramaturgo, Madrid, Comunidad de Madrid, 2005, pp. 99 115. 